\title{
Monitoring of Lutzomyia longipalpis Lutz \& Neiva, 1912 in an area of intense transmission of visceral leishmaniasis in Rio Grande do Norte, Northeast Brazil
}

\author{
Monitoramento de Lutzomyia longipalpis Lutz \& Neiva, 1912 em área de transmissão intensa \\ de leishmaniose visceral no Rio Grande do Norte, Nordeste do Brasil \\ Sthenia Santos Albano Amóra ${ }^{1,3}$; Claudia Maria Leal Bevilaqua ${ }^{1 *}$; Edmilson de Castro Dias²; \\ Francisco Marlon Carneiro Feijón; Paula Gabriela Melo de Oliveira ${ }^{3}$; Gislayne Christianne Xavier Peixoto ${ }^{3}$; \\ Nilza Dutra Alves ${ }^{3}$; Lorena Mayana Beserra de Oliveira ${ }^{1}$; Iara Térsia Freitas Macedo ${ }^{1}$ \\ ${ }^{1}$ Laboratório de Doenças Parasitárias, Programa de Pós-Graduação em Ciências Veterinárias - PPGCV, \\ Universidade Estadual do Ceará - UECE \\ ${ }^{2}$ Coordenadoria de Promoção à Saúde, Sub-Coordenadoria de Vigilância Ambiental, \\ Secretaria Estadual da Saúde Pública do Rio Grande do Norte - II URSAP \\ ${ }^{3}$ Laboratório de Microbiologia Veterinária, Universidade Federal Rural do Semi-Árido - UFERSA \\ Received June 26, 2009 \\ Accepted August 28, 2009
}

\begin{abstract}
Urban increase of visceral leishmaniasis (VL) in Brazil is associated with the adaptation of its vector, Lutzomyia longipalpis, to environments modified by humans. The present study reports the results of an entomological monitoring of L. longipalpis and the effect of environmental variables on its population density. Sandflies were captured in the municipality of Mossoró, State of Rio Grande do Norte, Northeastern Brazil, from January 2005 to December 2006. Two CDC light traps were placed monthly for four consecutive nights in the peridomicile of selected households. Data analysis was based on the chi-square test and linear regression. A total of 2,087 sandflies were captured, $99.86 \%$ of which were L. longipalpis. A higher proportion of females were captured ( $<0.05)$. Monthly analysis of the variables temperature, relative humidity and rainfall did not show a significant influence on population density. However, there were seasonal differences: approximately $70 \%$ of sand flies were captured during the rainy season $(\mathrm{p}<0.05)$. The predominant species, L. longipalpis, is present in substantial number, representing a public health risk. Therefore, because of higher prevalence during the rainy season, we recommend intensified VL control measures before and during this season to reduce the risk of disease transmission.
\end{abstract}

Keywords: Lutzomyia longipalpis, seasonality, epidemiology, vector control, visceral leishmaniasis.

\section{Resumo}

No Brasil, o crescimento urbano da leishmaniose visceral (LV) está associado com a adaptação do seu vetor, Lutzomyia longipalpis, aos ambientes modificados pelo homem. Este estudo relata a vigilância entomológica de L. longipalpis e os efeitos das variáveis ambientais sobre a sua densidade populacional. Os flebotomíneos foram capturados no município de Mossoró, Rio Grande do Norte, no Nordeste do Brasil, a partir de janeiro de 2005 a dezembro de 2006. Duas armadilhas tipo CDC foram colocadas mensalmente durante quatro noites consecutivas no peridomicílio das casas escolhidas. A análise dos dados foi baseada no teste Qui-quadrado e regressão linear. Um total de 2.087 flebotomíneos foram capturados, dos quais 99,86\% foram L. longipalpis. Mais fêmeas do que machos foram capturados $(\mathrm{p}<0,05)$. $\mathrm{Na}$ análise mensal das variáveis ambientais a temperatura, umidade relativa e a chuva não tiveram impacto significativo sobre a densidade populacional de L. longipalpis. No entanto, houve diferenças sazonais: aproximadamente $70 \%$ dos flebotomíneos foram capturados durante a estação chuvosa $(\mathrm{p}<0,05)$. Assim, L. longipalpis, a espécie predominante, representa um risco à saúde pública. Portanto, devido à maior prevalência no período chuvoso, recomendamos intensificar as medidas de controle da LV antes e durante este período para reduzir o risco de transmissão da doença.

Palavras-chave: Lutzomyia longipalpis, sazonalidade, epidemiologia, controle vetorial, leishmaniose visceral.

\footnotetext{
*Corresponding author: Claudia Maria Leal Bevilaqua

Laboratório de Doenças Parasitárias,

Programa de Pós-Graduação em Ciências Veterinárias - PPGCV,

Universidade Estadual do Ceará - UECE, Campus do Itaperi,

Av. Paranjana, 1700, Fortaleza, CEP 60740-000, Brasil

e-mail: claudiamlb@yahoo.com.br

Supported by: Dr. Bevilaqua is a CNPq researcher.
} 


\section{Introduction}

The importance of visceral leishmaniasis (VL) as a public health concern has increased significantly due to the urbanization process and changes in the natural environment (TRAVI et al., 2002). In Brazil, Lutzomyia longipalpis, remain the major vector in all regions including the southern region (SECRETARIA ESTADUAL DE SAÚDE DO RIO GRANDE DO SUL, 2009) and is found in all States of the Northeastern, Southeastern and Central-western region as well as in the capital Brasília (BOLETIM EPIDEMIOLÓGICO DO DISTRITO FEDERAL, 2009). Sand flies have a major role in the dynamics of $\mathrm{VL}$ transmission requiring in-depth investigation of their ecology to help formulating effective vector control measures, especially in regions where the disease is endemic (TEODORO et al., 2003).

Environmental factors such as temperature, relative humidity, and rainfall have different effect on sand fly population density (DIAS et al., 2007). Studies investigating seasonal variation of phlebotomine fauna can help better understand the interaction of each species with its habitat, as well as leishmaniasis transmission dynamics (MACEDO et al., 2008; MICHALSKY et al., 2009).

VL is endemic in the State of Rio Grande do Norte, Northeastern Brazil, and the transmission has steadily spread to other areas, as evidenced by an increasing number of municipalities reporting VL cases in recent years (AMÓRA et al., 2006; DUARTE et al., 2008; QUEIROZ et al., 2009). The purpose of the present study was to investigate the presence of $L$. longipalpis in an intense VL transmission area and to correlate the ecology of sand flies with environmental variables in this area.

\section{Materials and Methods}

\section{Study area}

The municipality of Mossoró is located $285 \mathrm{~km}$ from Natal, the capital of the State of Rio Grande do Norte. Its coordinates are $37^{\circ} 20^{\prime} 39^{\prime}$ W Longitude and 5 $5^{\circ} 11^{\prime} 15^{\prime}$ S Latitude. Occupying an area of 2,110.207 km², 85\% of Mossoró population $(234,390)$ is concentrated in an urban area (IBGE, 2007). The average annual temperature is approximately $27.5^{\circ} \mathrm{C}$. The average relative humidity is between 59 and $76 \%$. The climate is semiarid and characterized by low rainfall and two well-defined seasons: a rainy season, from January to April and extending as late as June (500 to $700 \mathrm{~mm} /$ year), and a dry season (IDEMA, 2002).

An entomological monitoring was conducted in a Mossoro neighborhood, Rincão, classified as subject to intense VL transmission based on mean number of human VL cases $\geq 4.4$ in the last five years (BRASIL, 2006).

\section{Capture and identification}

The study inclusion criteria for domiciles included recent history of $L$. longipalpis capture, presence of abundant vegetation in the peridomicile, domestic animals, and organic matter accumulation. The selected domiciles also had poor sanitary conditions. Captures were carried out monthly from January 2005 to December 2006 over four consecutive nights from 6:00 p.m. to 6:00 a.m. using CDC light traps. Two traps were placed at each domicile, one inside the household and the second one in the peridomicile area, preferably in animal shelters, as proposed by the Brazilian Ministry of Health (BRASIL, 2006).

The captured insects were identified at the Entomology Laboratory of the State Health Secretariat of Rio Grande do Norte. They were washed with saline solution and males were separated from females. Female specimens were then clarified and dissected on slides and covered with slips for observation under an optical microscope (ARANSAY; SCOULICA; TSELENTIS, 2000). Sandfly identification was performed according to Galati (2003).

\section{Data analysis}

Environmental variables including temperature $\left({ }^{\circ} \mathrm{C}\right)$, relative humidity (\%), and rainfall $(\mathrm{mm})$ information was obtained from the Universidade Federal Rural do Semi-Árido weather station. Male/female ratio and capture site were analyzed using the chi-square $\left(\chi^{2}\right)$ test. The correlation between environmental variables and sandfly population density was modeled using single or multiple linear regression analysis and the strength of the association was assessed by Pearson's correlation coefficient at $\mathrm{p}<0.05$ using SigmaStat 3.1 software (2004).

\section{Ethics committee}

The study was approved by the Research Ethics Committee of Universidade Estadual do Ceará as part of a research project entitled "Biological control and entomological surveillance of Lutzomyia longipalpis in the city of Mossoró, Rio Grande do Norte" (protocol n. 07465297-4).

\section{Results}

A total of 2,087 sand flies were captured, $99.86 \%$ of which were L. longipalpis $\left(\chi^{2}=1,037.51, \mathrm{df}=1, \mathrm{p}<0.05\right)$. The species was present in all months studied with a peak in April and July (Table 1). The remaining sandflies were Lutzomyia evandroi (COSTA LIMA; ANTUNES, 1936). During the study period, about $60 \%$ of $L$. longipalpis specimens captured were females, which was significantly higher than male specimens $\left(\chi^{2}=75.78\right.$, df $=1, \mathrm{p}<0.05)$.

The relative humidity ranged from 62 to $82 \%$, air temperature ranged from 26 to $29{ }^{\circ} \mathrm{C}$ and rainfall was between 0.0 and $242 \mathrm{~mm} / \mathrm{month}$. Environmental variables were statistically different only for monthly average rainfall. March and April were the wettest months $\left(\chi^{2}=3.37, \mathrm{df}=1, \mathrm{p}<0.05\right)$ (Table 1$)$.

The temperature remained almost constant during the study period. Nevertheless, humidity and insect capture peaks were irregularly distributed (Table 1). The analysis of monthly variables (temperature, relative humidity, and rainfall) did not show an effect on population density ( $\mathrm{p}>0.05)$. However, a comparison of the rainy and dry seasons showed that $78.45 \%$ of sandflies were 
Table 1. Entomological monitoring conducted in an area of intense transmission of visceral leishmaniasis in the State of Rio Grande do Norte, Northeastern Brazil, during 2005 and 2006.

\begin{tabular}{|c|c|c|c|c|c|c|}
\hline \multirow{2}{*}{ Months } & \multicolumn{3}{|c|}{ Lutzomyia longipalpis } & \multicolumn{3}{|c|}{ Environmental variables } \\
\hline & Female & Male & Total & Temperature $\left({ }^{\circ} \mathrm{C}\right)$ & Rainfall (mm) & Humidity (\%) \\
\hline January & $49 \mathrm{~A}$ & $31 \mathrm{~B}$ & $80 f$ & $29.43 a$ & $1.15 \mathrm{f}, \mathrm{g}$ & $65.36 \mathrm{a}$ \\
\hline February & $103 \mathrm{~A}$ & $48 \mathrm{~B}$ & $151 \mathrm{~d}, \mathrm{e}$ & $28.96 \mathrm{a}$ & $66.4 \mathrm{~d}$ & $69.93 a$ \\
\hline March & $34 \mathrm{~A}$ & $22 \mathrm{~A}$ & $56 \mathrm{~g}$ & $28.22 \mathrm{a}$ & $242.35 \mathrm{a}$ & $75.42 \mathrm{a}$ \\
\hline April & $320 \mathrm{~A}$ & $198 \mathrm{~B}$ & $518 \mathrm{a}$ & $27.55 \mathrm{a}$ & $188.5 b$ & $82.09 \mathrm{a}$ \\
\hline May & $94 \mathrm{~A}$ & $46 \mathrm{~B}$ & $140 \mathrm{~d}, \mathrm{e}$ & $27.05 \mathrm{a}$ & $94.05 c$ & $79.56 \mathrm{a}$ \\
\hline June & $142 \mathrm{~A}$ & $74 \mathrm{~B}$ & $216 c$ & $26.28 \mathrm{a}$ & $88.75 \mathrm{c}, \mathrm{d}$ & $78.41 \mathrm{a}$ \\
\hline July & $230 \mathrm{~A}$ & $129 \mathrm{~B}$ & $359 \mathrm{~b}$ & $27.13 \mathrm{a}$ & $23.80 \mathrm{e}$ & $67.62 \mathrm{a}$ \\
\hline August & $114 \mathrm{~A}$ & $56 \mathrm{~B}$ & $170 d$ & $27.70 \mathrm{a}$ & $19.80 \mathrm{e}$ & $63.61 \mathrm{a}$ \\
\hline September & $123 \mathrm{~A}$ & $83 \mathrm{~B}$ & $206 c$ & $28.22 \mathrm{a}$ & $4.85 \mathrm{f}$ & $65.07 \mathrm{a}$ \\
\hline October & $41 \mathrm{~A}$ & $11 \mathrm{~B}$ & $52 \mathrm{~g}$ & $28.78 \mathrm{a}$ & $0.00 \mathrm{~g}$ & $62.50 \mathrm{a}$ \\
\hline November & $12 \mathrm{~A}$ & $6 \mathrm{~A}$ & $18 \mathrm{~h}$ & $28.92 \mathrm{a}$ & $0.00 \mathrm{~g}$ & $74.55 a$ \\
\hline December & $61 \mathrm{~A}$ & $57 \mathrm{~A}$ & $118 \mathrm{e}$ & $29.12 \mathrm{a}$ & $0.00 \mathrm{~g}$ & $66.99 a$ \\
\hline
\end{tabular}

Upper case letters compare columns and lower case letters compare lines in the same column. Different letters indicate significantly different values by the chi-square test $(\mathrm{p}<0.05)$.

Table 2. Distribution of Lutzomyia longipalpis during the dry and the rainy seasons in 2005 and 2006 in an area of intense transmission of visceral leishmaniasis in the State of Rio Grande do Norte, Northeastern Brazil.

\begin{tabular}{cccc}
\hline Rainfall & Female & Male & Total \\
\hline Rainy period & $1,042 \mathrm{~A}, \mathrm{a}$ & $593 \mathrm{~B}, \mathrm{a}$ & $1,635 \mathrm{a}$ \\
Dry period & $281 \mathrm{~A}, \mathrm{~b}$ & $117 \mathrm{~B}, \mathrm{~b}$ & $168 \mathrm{~b}$ \\
Total & $1,323 \mathrm{~A}$ & $761 \mathrm{~B}$ & 2,084 \\
\hline
\end{tabular}

Upper case letters compare columns and lower case letters compare lines in the same column. Different letters indicate significantly different values by the chi-square test $(\mathrm{p}<0.05)$.

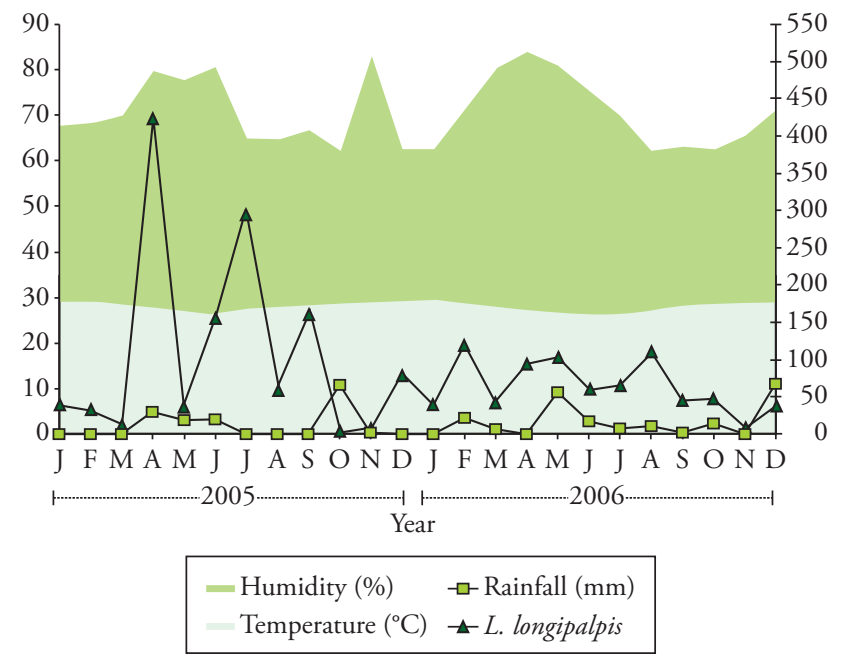

Figure 1. Influence of relative humidity and rainfall on Lutzomyia longipalpis population during an entomological monitoring in an area of intense visceral leishmaniasis transmission in the State of Rio Grande do Norte, Northeastern Brazil, from 2005 to 2006. captured during the rainy season $\left(\chi^{2}=596.81, \mathrm{df}=1, \mathrm{p}<0.05\right)$ (Table 2).

Figure 1 shows sandfly temporal variation and environmental variables. This vector assumes a characteristic seasonal distribution with increased density during rainy periods.

\section{Discussion}

Sandflies were captured in Mossoró monthly during the study period. The same pattern holds for other Brazilian States: Maranhão (REBÊLO, 2001), Minas Gerais (MONTEIRO et al., 2005) and Mato Grosso do Sul (OLIVEIRA et al., 2008). Ximenes et al. (2007) conducted a study in Mossoró and other municipalities in the State of Rio Grande do Norte, and demonstrated clear adaptation of $L$. longipalpis to the anthropic environment. L. evandroi has been found in the same ecotopes as L. longipalpis, but so far it has not been implicated as a leishmaniasis vector (LAINSON; RANGEL, 2005).

The same predominance of VL vector among captured sandflies in our study has also been demonstrated in several Brazilian States such as Ceará (DEANE, 1956), Pará (LAINSON et al., 1985), Amazonas (RIBEIRO; MISSAWA, 2002), Minas Gerais (MONTEIRO et al., 2005), Rio Grande do Norte (XIMENES et al., 2007; QUEIROZ et al., 2009), and Mato Grosso do Sul (OLIVEIRA et al., 2008) and even in other countries where the main VL vector is another species of sandfly, such as Lutzomyia cruzi in Mato Grosso do Sul (RIBEIRO; MISSAWA; ZEILHOFER, 2007), Lutzomyia evansi in Colombia (CORTÉS; FERNANDÉZ, 2008) and Lutzomyia pseudolongipalpis in western Venezuela (FELICIANGELI et al., 2006).

The finding of a higher proportion of females captured in Mossoró is similar to that described by Silva et al. (2008) in Paraná, Brazil, but contrasts with that reported in most other 
studies in Brazil (BARATA et al., 2008; OLIVEIRA et al., 2008; QUEIROZ et al., 2009; MICHALSKY et al., 2009).

Our results are similar to those of Barata et al. (2004), which showed climatic factors influencing sandfly population in the Brazilian municipality of Porteirinha, State of Minas Gerais, indicating a significant correlation between the number of sandflies and rainfall. Other studies have shown that the rainy period significantly affects insect population, with increased density also seen in the post-rainy period when humidity is high (GALATI et al., 2003; BARATA et al., 2004). Studies conducted in Campo Grande, State of Mato Grosso do Sul, Central-western Brazil (OLIVEIRA et al., 2008), and in Nísia Floresta, State of Rio Grande do Norte, Northeastern Brazil (XIMENES et al., 2006), as well as in Central-western Venezuela (FELICIANGELI et al., 2006), show that the highest $L$. longipalpis population density coincided with the rainy period.

Sandfly density increased during the rainy season, which was also reported in a study conducted in Belo Horizonte, State of Minas Gerais (RESENDE et al., 2006) and Rondônia (GIL et al., 2003). The rainy season is short and irregular in most Northeastern States in Brazil (XIMENES et al., 2006). During this season, moderate rain levels may favor the development of sandflies, but breeding sites are likely destroyed with ground flooding, killing the pupae in the soil. This suggests that sandfly seasonality is associated to rain distribution patterns, which act by modifying microenvironmental conditions (DIAS et al., 2007). In Belo Horizonte, the largest number of L. longipalpis were seen during the highest rainfall combined with the highest mean temperatures (RESENDE et al., 2006). These data corroborate our study, where the temperature remained relatively high and constant throughout the period studied.

The monthly analysis of the correlation between climatic factors and L. longipalpis population density in the present study did not show significant differences probably due to the lack of variation in relative humidity and temperature over the months studied, demonstrating that sandfly population increases are associated with rainfall. This has already been evidenced in other Brazilian cities such as Belo Horizonte, State of Minas Gerais (MARGONARI et al., 2004), São Luís, State of Maranhão (REBÊLO, 2001) and Campo Grande, State of Mato Grosso do Sul (OLIVEIRA et al., 2008).

In the present study, L. longipalpis insects are present in substantial number throughout the year, representing a public health risk. There are seasonal variations in the vector's distribution with increased density during rainy periods. Thus, we recommend intensified VL control measures in Mossoró before and during the rainy season to reduce the risk of disease transmission.

\section{Acknowledgments}

We thank Raimundo Nonato de Souza, Lindemberg Caranha de Sousa and Richristi A. Silva (Ceará State Health Secretariat) and Ana Claudia B. Mendonça and Sodré Rocha (Mossoró Municipal Health Secretariat) for help with sandfly field collections; Dr. Rui Sales Júnior and Dr. Celicina M. S. B. Azevedo (UFERSA) for their help; and the administrative staff of UFERSA for logistic support. We also thank the people of the areas studied for their cooperation and kindness.

\section{References}

AMÓRA, S. S. A. et al. Fatores relacionados com a positividade de cães para leishmaniose visceral em área endêmica do Estado do Rio Grande do Norte, Brasil. Ciência Rural, v. 36, n. 6, p. 1854-1859, 2006.

ARANSAY, A. M.; SCOULICA, E.; TSELENTIS, Y. Detection and identification of Leishmania DNA within naturally infected sand flies by seminested PCR on minicircle kinetoplastic DNA. Applied and Environmental Microbiology, v. 66, n. 5, p. 1933-1938, 2000.

BARATA, R. A. et al. Flebotomíneos do Parque Nacional Cavernas do Peruaçu, MG. Neotropical Entomology, v. 37, n. 2, p. 226-228, 2008.

BARATA, R. A. et al. Phlebotomines sand flies in Porteirinha, an endemic area of American visceral leishmaniasis in the State of Minas Gerais, Brazil. Memórias do Instituto Oswaldo Cruz, v. 99, n. 5 , p. 481-487, 2004.

BRASIL. Ministério da Saúde. Manual de vigilância e controle da leishmaniose visceral. Brasília, 2006. 122 p. Disponível em: <http:// portal.saude.gov.br/portal/arquivos/pdf/manual_leish_visceral2006. pdf $>$. Acesso em: 30 de agosto de 2008.

CORTÉS, L. A.; FERNÁNDEZ, J. J. Species of Lutzomyia involved in an urban focus of visceral and cutaneous leishmaniasis. Biomedica, v. 28, n. 3 , p. $433-440,2008$

DEANE, L. M. Leishmaniose Visceral no Brasil: estudos sobre reservatórios e transmissores realizados no Estado do Ceará. Rio de Janeiro: Serviço Nacional de Educação Sanitária, 1956. 162 p.

DIAS, E. S. et al. Flebotomíneos (Diptera: Psychodidae) de um foco de leishmaniose tegumentar no Estado de Minas Gerais. Revista da Sociedade Brasileira de Medicina Tropical, v. 40, n. 1, p. 49-52, 2007.

BRASIL. Secretaria de Estado de Saúde do Distrito Federal. Núcleo de Controle de Endemias e Doenças Transmissíveis Emergentes. Leishmaniose Visceral. Brasília, 2009. 7 p. (Boletim Epidemiológico do Distrito Federal, 1) Disponível em: <http://www.saude.df.gov.br/ sites/300/373/00000262.pdf>. Acesso em: 30 de setembro de 2009.

DUARTE, D. et al. Fatores associados ao risco de infecção por Leishmania e de desenvolvimento de leishmaniose visceral: o exemplo do Rio Grande do Norte, Brasil. Revista da Sociedade Brasileira de Medicina Tropical, v. 41, supl. 3, p. 168-171, 2008.

FELICIANGELI, M. D. et al. Leishmania and sand flies: proximity to woodland as a risk factor for infection in a rural focus of visceral leishmaniasis in west central Venezuela. Tropical Medicine \& International Health, v. 11, n. 12, p. 1785-1791, 2006.

GALATI, E. A. B. Morfologia e taxonomia: morfologia, terminologia de adultos e identificação dos táxons da América. In: RANGEL, E. F; LAINSON, R. Flebotomíneos do Brasil. Rio de Janeiro: Fiocruz, 2003. p. 53-175.

GALATI, E. A. B. et al. Phlebotomines (Diptera, Psychodidae) in caves of the Serra da Bodoquena, Mato Grosso do Sul State, Brazil. Revista Brasileira de Entomologia, v. 47, n. 2, p. 283-296, 2003.

GIL, L. H. S. et al. Recent Observations on the Sand Fly (Diptera: Psychodidae) Fauna of the State of Rondônia, Western Amazônia, Brazil: the importance of Psychdopygus davisi as a Vector of Zoonotic Cutaneous Leishmaniasis. Memórias do Instituto Oswaldo Cruz, v. 98, n. 6 , p. $751-755,2003$.

INSTITUTO BRASILEIRO DE GEOGRAFIA E ESTATÍSTICA IBGE. Populaçáo recenseada e estimada, segundo os municípios, Rio 
Grande do Norte. Rio de Janeiro, 2007. Disponível em: <http://www. ibge.gov.br>. Acesso em: 30 de agosto de 2008.

INSTITUTO DE DEFESA DO MEIO AMBIENTE - IDEMA. Governo do Rio Grande do Norte: perfil do seu Município. Rio Grande do Norte, 2008. Disponível em: <http://www.rn.gov.br>. Acesso em: 30 de agosto de 2008 .

LAINSON, R. et al. Leishmaniasis in Brazil XXI: Visceral leishmaniasis in the Amazon Region and further observations on the role of Lutzomyia longipalpis (Lutz \& Neiva, 1912) as the vector. Transactions of the Royal Society of Tropical Medicine and Hygiene, v. 79, n. 2, p. 223-226, 1985.

LAINSON, R.; RANGEL, E. F. Lutzomyia longipalpis and the ecoepidemiology of American visceral leishmaniasis, with particular reference to Brazil: a review. Memórias do Instituto Oswaldo Cruz, v. 100, n. 8 , p. 811-827, 2005.

MACEDO, I. T. F. et al. Sazonalidade de flebotomíneos em área endêmica de leishmaniose visceral no município de Sobral, Ceará, Brasil. Ciência Animal, v. 18, n. 2, p. 67-74, 2008.

MARGONARI, C. S. et al. Study on phlebotomine sand fly (Diptera: Psychodidae) fauna in Belo Horizonte, State of Minas Gerais, Brazil. Memórias do Instituto Oswaldo Cruz, v. 99, n. 8, p. 795-803, 2004

MICHALSKY, E. M. et al. Phlebotominae distribution in Janaúba, an area of transmission for visceral leishmaniasis in Brazil. Memórias do Instituto Oswaldo Cruz, v. 104, n. 1, p. 56-61, 2009.

MONTEIRO, E. M. et al. Leishmaniose visceral: estudo de flebotomíneos e infecção canina em Montes Claros, Minas Gerais. Revista da Sociedade Brasileira de Medicina Tropical, v. 38, n. 2, p. 147-152, 2005.

OLIVEIRA, A. G. et al. Seasonal variation of Lutzomyia longipalpis (LUTZ and NEIVA, 1912) (Diptera: Psychodidae: Phlebotominae) in endemic area of visceral leishmaniasis, Campo Grande, state of Mato Grosso do Sul, Brazil. Acta Tropica, v. 105, n. 1, p. 55-61, 2008.

QUEIROZ, P. V. S. et al. Canine visceral leishmaniasis in urban and rural areas of Northeast Brazil. Research in Veterinary Science, v. 86, n. 2, p. 267-273, 2009.

REBÊLO, J. M. M. Freqüência horária e sazonalidade de Lutzomyia longipalpis (Diptera: Psychodidae: Phlebotominae) na Ilha de São Luís,
Maranhão, Brasil. Cadernos de Saúde Publica, v. 17, n. 1, p. 221-227, 2001.

RESENDE, M. C. et al. Seasonal variation of Lutzomyia longipalpis in Belo Horizonte, State of Minas Gerais. Revista da Sociedade Brasileria de Medicina Tropical, v. 39, n. 1, p. 51-55, 2006.

RIBEIRO, A. L.; MISSAWA, N. A. Spatial distribution of phlebotomine species in the state of Mato Grosso, Brazil, in the period of 1996 to 2001. Entomología y Vectores, v. 9, n. 1, p. 33-34, 2002.

RIBEIRO, A. L.; MISSAWA, N. A.; ZEILHOFER, P. Distribution of phlebotomine sandflies (Diptera: Psychodidae) of medical importance in Mato Grosso State, Brazil. Revista do Instituto de Medicina Tropical de Sáo Paulo, v. 49, n. 5, p. 317-321, 2007.

RIO GRANDEDOSUL. Secretaria Estadual deSaúde. Núcleo de Vigilância dos Riscos e Agravos Ambientais Biológicos. Situaçáo da Leishmaniose Visceral no RS. Rio Grande do Sul, 2009. Disponível em: <http://www. saude.rs.gov.br/dados/1239825393188SITUA\%C7\%C3O\%20NO\%20 RS.pdf>. Acesso em: 30 de setembro de 2009.

SILVA, A. M. et al. Diversidade, distribuição e abundância de Flebotomíneos (Diptera: Psychodidae) no Paraná. Neotropical Entomology, v. 37, n. 2, p. 209-225, 2008.

TEODORO, U. et al. Influência da reorganização, da limpeza do peridomicílio e a da desinsetização de edificaçôes na densidade populacional de flebotomíneos no Município de Doutor Camargo, Estado do Paraná, Brasil. Cadernos de Saúde Publica, v. 19, n. 6, p. 1801-1813, 2003.

TRAVI, B. L. et al. Impact of habitat degradation on phlebotominae (Diptera: Psychodidae) of tropical dry forests in Northern Colombia. Journal of Medical Entomology, v. 39, n. 3, p. 451-456, 2002.

XIMENES, M. F. F. M. et al. Effect of Abiotic Factors on Seasonal Population dynamics of Lutzomyia longipalpis (Diptera: Psychodidae) in Northeastern Brazil. Journal of Medical Entomology, v. 43, n. 5, p. 990-995, 2006.

XIMENES, M. F. F. M. et al. Flebotomíneos (Diptera: Psychodidae) e leishmanioses no Rio Grande do Norte, Nordeste do Brasil: reflexos do ambiente antrópico. Neotropical Entomology, v. 36, n. 1, p. 128-137, 2007. 